\title{
Compressive Properties of Amorphous Metal Fiber Reinforced Concrete Exposed to high Temperature
}

\author{
Lee, Jun-Cheol Kim, Wha-Jung Lee, Chang-Joon* \\ School of Architecture and Civil of Engineering, Kyungpook National University, Buk-Gu, Daegu, 702-701, Korea
}

\begin{abstract}
Compressive property of high strength concrete with amorphous metal fibers subject to high temperature has been investigated. The measure of this investigation includes explosive spalling, weight loss, residual compressive strength, strain at peak stress, elastic modulus, and residual energy absorption capacity after exposure to $400^{\circ} \mathrm{C}, 600^{\circ} \mathrm{Cand} 800^{\circ} \mathrm{C}$. In addition to the amorphous metal fiber, two other types of fibers (polypropylene fiber and hooked-end steel fiber) were also included in this investigation for comparison. The experimental program was conducted with high strength concrete using several combinations of the fiber types. The testing result shows that the concrete with amorphous metal fibers plus polypropylene fibers shows a superior behavior than those using other combination or single fiber type ingredient.
\end{abstract}

Keywords : amorphous metal fiber, fiber reinforced concrete, explosive spalling, compressive material properties

\section{Introduction}

High strength concrete (HSC) is superior to normal strength one in terms of its mechanical strength, stiffness and also durability due to its intrinsic characteristic of microstructure, dense matrix with low volume of disconnected voids. However, this beneficial microstructure causes a critical problem, explosive spalling, when the material undergoes high temperature for a certain period of time. Under a high temperature condition, internal vapor pressure developed in isolated voids cannot be discharged through the dense structure hence initiates micro cracks and finally spalls abruptly [1].

\section{Received : October 14, 2011}

Revision received : February 1, 2012

Accepted : February 17, 2012

* Corresponding author : Lee, Chang-Joon

[Tel: 82-53-950-4767, E-mail: cjlee0000@gmail.com]

(c)2012 The Korea Institute of Building Construction, All rights reserved.
In order to solve the explosive spalling problem, many researchers utilizes synthetic polymer, steel, or both fibers as an essential ingredient of high strength concrete. These types of fibers play different roles under high temperature environment. The synthetic fibers are melted at a certain level of temperature below the "spalling temperature" and provide some paths for the vapors. The discharged vapors through the paths reduce the internal vapor pressure and prevent the abrupt spalling. Although the synthetic fibers prevent the abrupt spalling, they cannot improve the residual strength due to the additional voids, the paths [2]. On the other hand, steel fibers confine the concrete matrix and improve the tensile strength of the composite hence show a good residual strength. However, in many cases, the steel fiber composite shows the spalling when exposed to high temperature [3]. The remedy of the weakness of each fiber composite is the use of both fibers in concrete, i.e. synthetic fibers 
prevent the spalling and steel fibers strengthen the composite material [4].

Although the steel fibers provides a good performance in the residual strength, mechanical properties of steel are dramatically degraded at high temperatures hence the benefit of the steel fiber in concrete is not as good as in room temperature. In this sense, if one finds a better performing metallic fiber in high temperatures, one may produce a better performing concrete. In other words, a fabric metal material showing less degradation in mechanical properties at high temperatures may enhance the overall performance of HSC under high temperature and also in the residual performance. One of the candidates for the replacement of the steel fiber could be amorphous metal fibers (AMF).

Usual metals including steel have highly ordered atomic-scale structure which means they are highly crystalline. The crystalline of metal limits the gain of mechanical properties due to the intrinsic defects such as dislocations. In contrast to this, an amorphous metal has disordered non-crystalline atomic-scale structure hence it is literally free from the defects and shows much better mechanical properties such as high strength, high elastic moduli, high resistance to wear and corrosion, etc. With this benefit, some researchers tried to replace steel fibers with amorphous metal fibers (AMF) for a room temperature application and showed the superior performance than steel fiber reinforced concretes [5].

It is reported, under a high temperature condition, some proportion of amorphous metal experiences phase changes and turns into a crystalline structure but some other proportion of the material still remains in non-crystalline structure[6], hence we expect the benefit of amorphous metal even in a higher temperature condition. Therefore, in addition to room temperature applications, we may also expect a better performance of HSC with AMF under high temperature since the fabric material (AMF) will show less degradation than normal steel fibers.

This study is intended to assess the compressive material behavior of HSC with AMF under high temperature condition to establish basic data with which evaluate the residual strength of a structure in a fire. The compressive behavior evaluated in this study includes the residual compressive strength, elastic modulus, and residual energy absorption capability.

\section{Experimental program}

\subsection{Design of experiment}

Although the main interest of the study is the performance of HPC with AMF under high temperature condition, we also included several concrete materials with various fiber mixture conditions into the experimental program in order to compare the performance with each other.

The details of experimental program are shown in Table 1. The experimental program designed for one plain concrete (HPC), three single fiber FRCs (PHPC, SHPC and AHPC), and two hybrid fiber FRCs (PSHPC and PAHPC).

The mixture proportion of the plain concrete is shown in Table 2. The plain concrete was designed to achieve a 28-day compressive strength of about $60 \mathrm{MPa}$. The concrete mixture was prepared at a water-to-binder ratio of 0.26 . The mixture proportions of concrete were determined to satisfy air content of $3.5 \pm 1.0 \%$ and target slump-flow of $550 \pm 150 \mathrm{~mm}$.

The fiber contents used were $0.91 \mathrm{~kg} / \mathrm{m}^{3}(0.1 \%$ by volume) for the polypropylene fibers, $7.85 \mathrm{~kg} / \mathrm{m}^{3}$ (1.0\% by volume) for the steel fibers and $3.7 \mathrm{~kg} / \mathrm{m}^{3}$ (0.5\% by volume) for the amorphous metal fibers. 
The hybrid mixes included the polypropylene fibers were the combination of $50 \%$ of the previous contents for respective fiber types, i.e., $0.45 \mathrm{~kg} / \mathrm{m}^{3}$ of polypropylene fibers plus $3.9 \mathrm{~kg} / \mathrm{m}^{3}$ of steel fibers and $0.45 \mathrm{~kg} / \mathrm{m}^{3}$ of polypropylene fibers plus $1.8 \mathrm{~kg} / \mathrm{m}^{3}$ of amorphous metal fibers.

Table 1. Experimental design of fiber reinforced concrete materials

\begin{tabular}{|c|c|c|c|c|c|c|c|}
\hline \multirow{2}{*}{ Type } & \multirow{2}{*}{$\begin{array}{l}\text { W/B } \\
(\%)\end{array}$} & \multirow{2}{*}{$\begin{array}{c}\text { Air } \\
\text { content } \\
(\%)\end{array}$} & \multirow{2}{*}{$\begin{array}{l}\text { Admixture } \\
(\%)\end{array}$} & \multirow{2}{*}{$\begin{array}{l}\text { Slump } \\
\text { flow } \\
(\mathrm{mm})\end{array}$} & \multicolumn{3}{|c|}{ Fiber (vol.\%) } \\
\hline & & & & & PPF & SF & AMF \\
\hline $\mathrm{HPC}$ & & & & & 0 & 0 & 0 \\
\hline PHPC & & & & & 0.10 & 0 & 0 \\
\hline SHPC & & & & 550 & 0 & 1.0 & 0 \\
\hline AHPC & 26 & $3.5 \pm 1.0$ & 10 & \pm 150 & 0 & 0 & 0.50 \\
\hline PSHPC & & & & & 0.05 & 0.5 & 0 \\
\hline PAHPC & & & & & 0.05 & 0 & 0.25 \\
\hline
\end{tabular}

Table 2. Mixture proportion for plain concrete

\begin{tabular}{|c|c|c|c|c|c|c|}
\hline \multirow{3}{*}{$\begin{array}{c}\text { W/B } \\
(\%)\end{array}$} & \multirow{3}{*}{$\begin{array}{l}\text { S/a } \\
(\%)\end{array}$} & \multirow{3}{*}{$\begin{array}{l}\text { SP } \\
(\%)\end{array}$} & \multicolumn{4}{|c|}{ Unit weight $\left(\mathrm{kg} / \mathrm{m}^{3}\right)$} \\
\hline & & & \multicolumn{2}{|c|}{ Binder } & \multirow{2}{*}{ S } & \multirow{2}{*}{ G } \\
\hline & & & OPC & Silica fume & & \\
\hline 26 & 42 & 1.0 & 597 & 59 & 702 & 961 \\
\hline
\end{tabular}

NOTE: $\mathrm{W} / \mathrm{B}=$ water to binder ratio, $\mathrm{S} / \mathrm{a}=$ sand to coarse aggregate ratio, $\mathrm{SP}=$ superplasticizer, $\mathrm{OPC}=$ ordinary Portland cement, $\mathrm{S}=$ Sand, $\mathrm{G}=$ Gravel

\subsection{Materials}

The cementitious materials used in this study were ordinary Portland cement (OPC) equivalent to KS L 1201 Type I and silica fume with a grain size of $0.15 \mathrm{um}$. A usual river sand and crushed granite stone with maximum size of $13 \mathrm{~mm}$ was used as fine and coarse aggregates, respectively. A superplasticizer based on polycarbonic acid was used at a dosage from 1.0\% 1.5\% of binder contents in order to maintain slump of mixtures.
Figure 1 shows the shape of each fiber used in this study. The polypropylene fibers have a length of $19 \mathrm{~mm}$ with aspect ratio of 475 . The steel fibers were hooked-end fibers with a length of $50 \mathrm{~mm}$ and aspect ratio of 71 . The amorphous metal fibers were amorphous $\mathrm{Fe}$-base metals with a length of $30 \mathrm{~mm}$ and thickness of $0.026 \mathrm{~mm}$. The physical properties of each fiber are presented in Table 3 through Table 5.

Table 3. Properties of polypropylene fiber

\begin{tabular}{ccccccc}
\hline Type & $\begin{array}{c}\text { Melting } \\
\text { Temp. }\end{array}$ & $\begin{array}{c}\text { Diameter } \\
(\mathrm{mm})\end{array}$ & $\begin{array}{c}\text { Length } \\
(\mathrm{mm})\end{array}$ & $\begin{array}{c}\text { Aspect } \\
\text { ratio }\end{array}$ & $\begin{array}{c}\text { Density } \\
\left(\mathrm{g} / \mathrm{m}^{3}\right)\end{array}$ & $\begin{array}{c}\text { Tensile } \\
\text { strength } \\
(\mathrm{MPa})\end{array}$ \\
\hline Straight & 165 & 0.04 & 19 & 475 & 0.91 & 550 \\
\hline
\end{tabular}

Table 4. Properties of steel fiber

\begin{tabular}{cccccc}
\hline Type & $\begin{array}{c}\text { Diameter } \\
(\mathrm{mm})\end{array}$ & $\begin{array}{c}\text { Length } \\
(\mathrm{mm})\end{array}$ & $\begin{array}{c}\text { Aspect } \\
\text { ratio }\end{array}$ & $\begin{array}{c}\text { Density } \\
\left(\mathrm{g} / \mathrm{m}^{3}\right)\end{array}$ & $\begin{array}{c}\text { Tensile } \\
\text { strength } \\
(\mathrm{MPa})\end{array}$ \\
\hline $\begin{array}{c}\text { Bundle } \\
\text { (Hooked } \\
\text { end })\end{array}$ & 0.7 & 50 & 71 & 7.85 & 1,100 \\
\hline
\end{tabular}

Table 5. Properties of amorphous metal fiber

\begin{tabular}{cccccc}
\hline Type & $\begin{array}{c}\text { Specific } \\
\text { gravity } \\
\left(\mathrm{g} / \mathrm{m}^{3}\right)\end{array}$ & $\begin{array}{c}\text { Thickness } \\
(\mathrm{mm})\end{array}$ & $\begin{array}{c}\text { Width } \\
(\mathrm{mm})\end{array}$ & $\begin{array}{c}\text { Length } \\
(\mathrm{mm})\end{array}$ & $\begin{array}{c}\text { Tensile } \\
\text { strength } \\
(\mathrm{MPa})\end{array}$ \\
\hline Straight & 7.4 & 0.026 & 0.2 & 30 & 1,700 \\
\hline
\end{tabular}

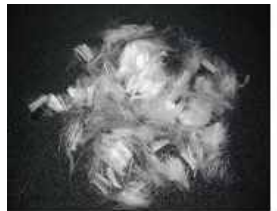

(a)

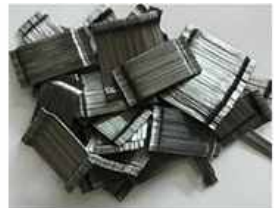

(b)

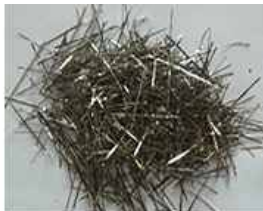

(c)
Figure 1. Shape of fibers; (a) Polypropylene fiber, (b) Steel fiber (c) Amorphous metal fiber

\subsection{Specimen preparation and test}

A pan mixer was used for mixing concrete. As for the fresh concrete properties, the value of slump-flow was measured after slump test carried 
out according to ASTM C143 [7], and also air contents of all mixtures were measured according to ASTM 231 [8].

For each mixture, a total of twelve $100 \mathrm{~mm}$ (diameter) $\times 200 \mathrm{~mm}$ (height) cylinders were cast in steel moulds. Specimens were cured in a temperature controlled water bathe at $20 \pm 3^{\circ}$ Cuntil the age of 27 days, and then kept in air for 1 day.

Compressive strength test was carried out according to ASTM C39 with three specimens [9]. The axial deformations were measured using two LVDTs mounted on opposite sides of the specimen with a gage length of $50 \mathrm{~mm}$, according to JSCE-SF5 [10]. Figure 2 shows the test setup for measuring deformation.

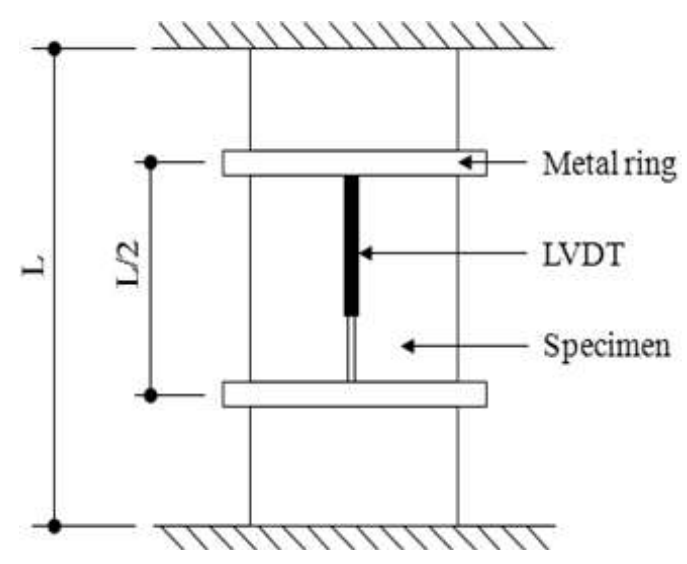

Figure 2. Test setup for measuring deformation

The remaining nine specimens were subjected to three temperature exposure conditions in an electric furnace. Three were heated to $400^{\circ} \mathrm{C}$, other three to $600^{\circ} \mathrm{C}$, and the other three to $800^{\circ} \mathrm{C}$. This study did not include the heating temperature of $200^{\circ} \mathrm{C}$ since it has been shown in the previous studies that heating to temperature of $200^{\circ} \mathrm{C}$ does not have significant effects on compressive strength of concrete $[11,12,13]$.

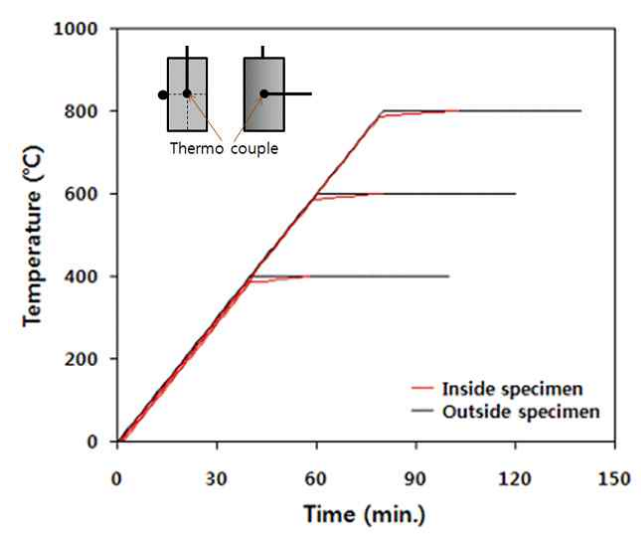

Figure 3. Temperature curve of specimen

Specimens were heated in an electric furnace at the rate of $10^{\circ} \mathrm{C} / \mathrm{min}$ until reaching target temperature. The target temperature was maintained for $1 \mathrm{hr}$. The duration of $1 \mathrm{hr}$ was based a preliminary investigation which showed temperature at the center of a specimen rose gradually to the target temperature from the first 20 minutes during the $1 \mathrm{hr}$ period for maintaining temperature. After the $1 \mathrm{hr}$ duration, the specimens were left in the furnace for 40 minutes until electric heating was turned off. Figure 3 shows the temperature curve of a specimen. After exposure to the high temperatures, the uniaxial compressive test was conducted as the same way to the unheated concrete specimens. The weight loss of each specimen was also measured.

\section{Experimental Result}

\subsection{Characteristics of fresh concrete}

Table 6 shows the characteristics of fresh concrete according to the type of mixed fiber. The air content and slump flow satisfy the target values, but they vary according to the fiber types within the target range. The slump flow was lowest in the concrete mixed with amorphous metal fiber (AHPC and PAHPC). It seems that the amorphous metal fiber reduces the fluidity of 
concrete because its specific area is larger than those of PP fiber and steel fiber.

Table 6. Properties of fresh concrete

\begin{tabular}{ccc}
\hline Type & Air contents $(\%)$ & Slump flow $(\mathrm{mm})$ \\
\hline HPC & 4.2 & 690 \\
PHPC & 4.3 & 640 \\
SHPC & 4.1 & 570 \\
AHPC & 3.9 & 440 \\
PSHPC & 4.0 & 520 \\
PAHPC & 3.8 & 440 \\
\hline
\end{tabular}

\subsection{Characteristics of hardened concrete at room temperature}

Figure 4 shows the compressive stress-strain curve of the hardened concrete at room temperature according to the type of the mixed fiber. Based on these stress-strain curves, several mechanical properties are extracted including compress strength, strain at peak stress, area under stress-strain curve, specific toughness ratio. Table 7 shows these properties according to the fiber type.

\subsubsection{Strain at peak stress}

The concrete mixed with fiber had 0.01-0.04\% higher strain values than the concrete with which no fiber was mixed. This seems to have been because of the fine cracks and the confinement effect of the reinforcement fiber on the concrete under the compressive stress, as in the results of previous studies [14]. The strain at maximum compressive stress was largest when the concrete was mixed with PP fiber and steel fiber (PSHPC). When the fibers were hybridized, the strain under maximum stress was $0.02-0.03 \%$ higher than when only one fiber was mixed.
Table 7. Test results for unheated concrete

\begin{tabular}{ccccc}
\hline Type & $\begin{array}{c}\text { Compressive } \\
\text { strength } \\
(\mathrm{MPa})\end{array}$ & $\begin{array}{c}\text { Strain at } \\
\text { peak } \\
\text { stress } \\
(\%)\end{array}$ & $\begin{array}{c}\text { Area under } \\
\text { stress-strain } \\
\text { curve } \\
\left(\mathrm{MPa} \times 10^{-2}\right)\end{array}$ & $\begin{array}{c}\text { Specific } \\
\text { toughness } \\
\text { ratio } \\
(\%)\end{array}$ \\
\hline HPC & 75.83 & 0.25 & 18.15 & 0.24 \\
PHPC & 59.73 & 0.26 & 22.72 & 0.38 \\
SHPC & 76.44 & 0.26 & 36.49 & 0.48 \\
AHPC & 65.95 & 0.27 & 32.45 & 0.49 \\
PSHPC & 67.48 & 0.29 & 28.76 & 0.43 \\
PAHPC & 71.73 & 0.28 & 31.79 & 0.44 \\
\hline
\end{tabular}

\subsubsection{Compressive strength}

Figure 5 shows the compressive strength of hardened concrete at the age of 3,7 and 28 days. All the test specimens other than SHPC showed lower compressive strength compared to the control mixture regardless the material age. The compressive strength of PHPC showed the largest decrease (21.2\%) from that of control mixture. The compressive strength of AHPC is decreased by 13.0\% from the control mixture. On the other hand, SHPC showed 0.8\% strength increase. The compressive strength of PSHPC showed a decrease of $11.0 \%$ from the control mixture, which was larger than SHPC. The compressive strength of PAHPC showed a decrease of $5.4 \%$ from control mixture, which was smaller than PHPC.

\subsubsection{Compressive toughness ratio}

Figure 6 shows the definition of the compressive toughness ratio of the fiber-reinforced concrete. The compressive toughness is defined as the area below the stress-strain curve (A) at the reference strain. The toughness ratio is calculated by dividing A by the maximum compressive strength [15]. In this study, with the strain of $0.75 \%$ that had been used in JSCE-SF5 and previous studies of Nataraja [16] and C.S. Poon[4] as the reference, the area below the stress-strain curve was calculated to evaluate the compressive toughness ratio. 

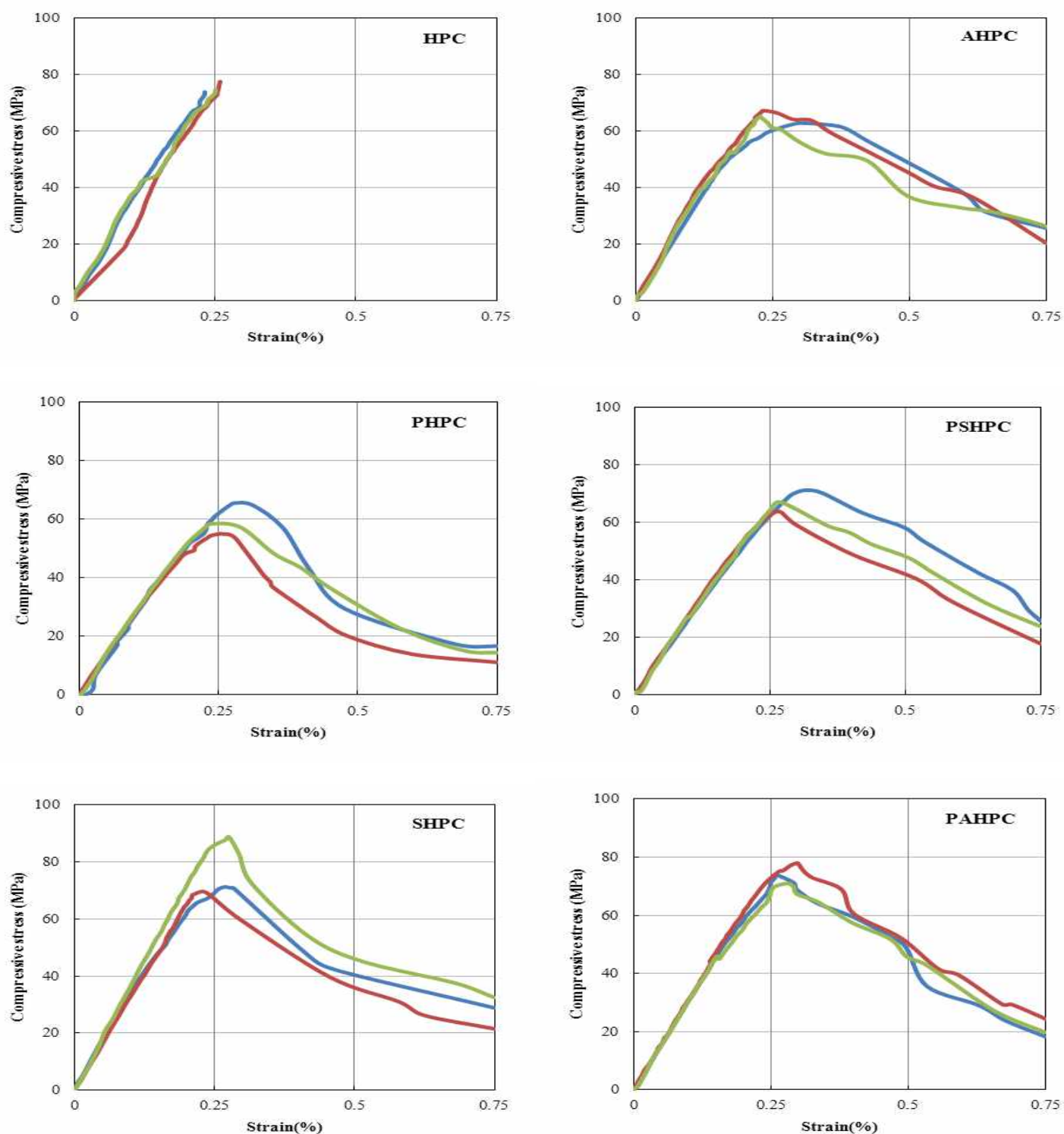

Figure 4. Stress-strain curves for unheated concrete materials

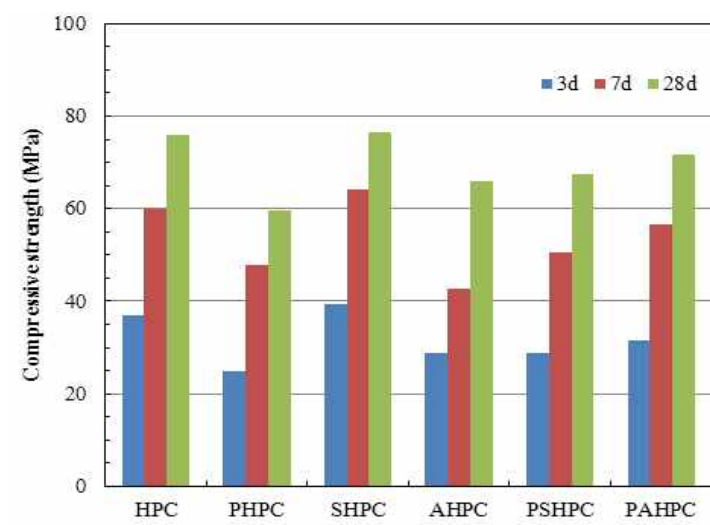

Figure 5. Compressive strength of unheated concrete

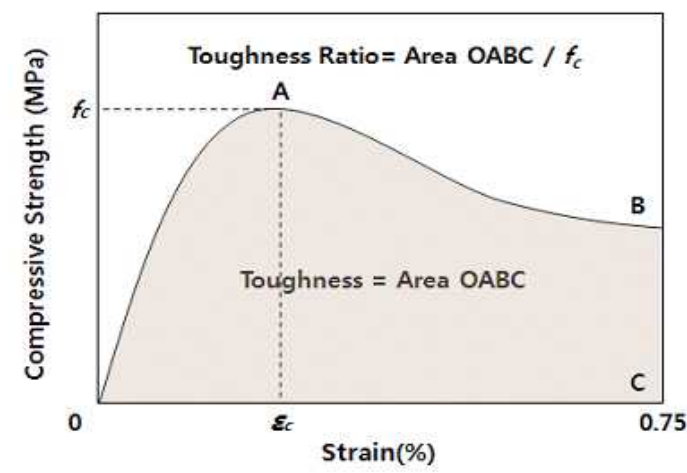

Figure 6. Definition of compressive toughness 
Figure 7. Occurrence of explosive spalling

\begin{tabular}{|c|c|c|c|c|c|c|}
\hline Type & HPC & $\overline{\mathrm{PHPC}}$ & SHPC & $\overline{\mathrm{AHPC}}$ & PSHPC & PAHPC \\
\hline $400^{\circ} \mathrm{C}$ & & & & & & \\
\hline $600^{\circ} \mathrm{C}$ & $N / A$ & & $\mathrm{~N} / \mathrm{A}$ & $N / A$ & & \\
\hline $800^{\circ} \mathrm{C}$ & $\mathrm{N} / \mathrm{A}$ & & $\mathrm{N} / \mathrm{A}$ & $N / A$ & & \\
\hline
\end{tabular}

Table 7 shows the evaluation results. The results showed that the compressive toughness of the fiber-mixed concrete was substantially higher than that of the concrete to which no fiber was mixed. The compressive toughness of SHPC and AHPC was especially high as $0.49 \%$ and $0.48 \%$ respectively. The compressive toughness of PHPC was lowest as 0.38\%. The concrete mixed with hybrid fibers (PSHPC and PAHPC) shows about $0.05 \%$ lower value compared to those with single metal fiber ingredient (SHPC and APHPC).

\subsection{Behavior of concrete after exposure to high temperature}

\subsubsection{Explosive spalling}

Figure 7 shows the result of explosive spalling. After exposure to $400^{\circ} \mathrm{C}, \mathrm{HPC}, \mathrm{SHPC}$ and AHPC suffered significant spalling. On the other hand, concretes using polypropylene fibers (PHPC, PSHPC and PAHPC) behaved quite well until $800^{\circ} \mathrm{C}$.

\subsubsection{Weight reduction}

Figure 8 shows the relative weight of specimens after exposure to high temperature. The relative weight was defined as the weight of specimen after heating to that at room temperature. Note that the figure shows only for the non-spalled mixtures (PHPC, PSHPC, PAHPC).
There was no significant difference in the weight loss among the different fiber types. The PAHPC shows slightly higher weight reduction at higher temperatures $\left(600^{\circ} \mathrm{C}, 800^{\circ} \mathrm{C}\right)$ compared to $\mathrm{PHPC}$ or PAHPC. On an average, the weight reduction rate was $6.5 \%$ at $400^{\circ} \mathrm{C}, 7.8 \%$ at $600^{\circ} \mathrm{C}$, and $8.8 \%$ at $800^{\circ} \mathrm{C}$.

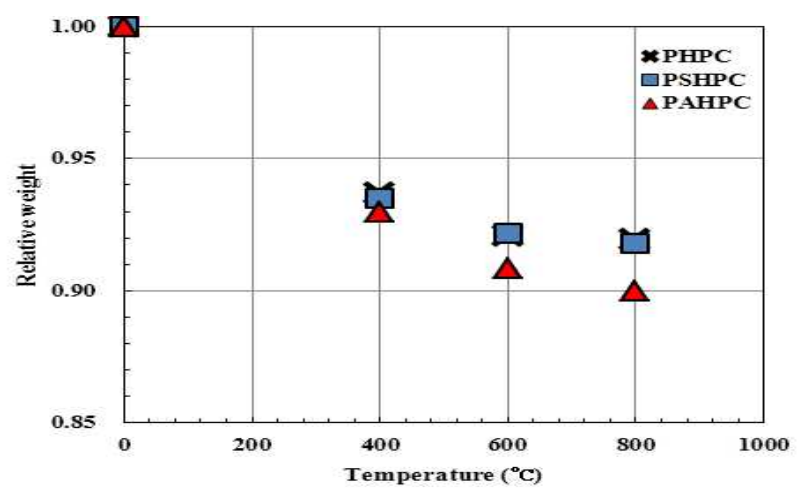

Figure 8. Relative weight

Table 8. Test results for heated concrete

\begin{tabular}{|c|c|c|c|c|}
\hline $\begin{array}{c}\text { Temperature } \\
\left({ }^{\circ} \mathrm{C}\right)\end{array}$ & Type & $\begin{array}{c}\text { Compressive } \\
\text { strength } \\
\text { (MPa) }\end{array}$ & $\begin{array}{c}\text { Strain at } \\
\text { peak } \\
\text { stress } \\
(\%)\end{array}$ & $\begin{array}{c}\text { Area under } \\
\text { stress -strain } \\
\text { curve } \\
\left(\mathrm{MPa} \times 10^{-2}\right)\end{array}$ \\
\hline \multirow{3}{*}{400} & PHPC & 44.90 & 0.31 & 18.64 \\
\hline & PSHPC & 45.79 & 0.35 & 20.08 \\
\hline & PAHPC & 61.35 & 0.35 & 25.29 \\
\hline \multirow{3}{*}{600} & PHPC & 24.65 & 0.44 & 10.62 \\
\hline & PSHPC & 26.22 & 0.56 & 11.68 \\
\hline & PAHPC & 39.39 & 0.54 & 17.15 \\
\hline \multirow{3}{*}{800} & PHPC & 13.28 & 0.62 & 5.85 \\
\hline & PSHPC & 22.51 & 0.71 & 7.11 \\
\hline & PAHPC & 27.29 & 0.68 & 8.59 \\
\hline
\end{tabular}




\subsubsection{Residual compressive strength}

Figure 9 shows the compressive stress-strain curve of the hardened concrete after exposure to high temperature according to the type of the mixed fiber. Note that the curves are only for the non-spalled mixtures (PHPC, PSHPC, PAHPC). Based on these stress-strain curves, several mechanical properties are extracted including compress strength, strain at peak stress, area under stress-strain curve, specific toughness ratio. Table 8 shows these properties according to the fiber type.

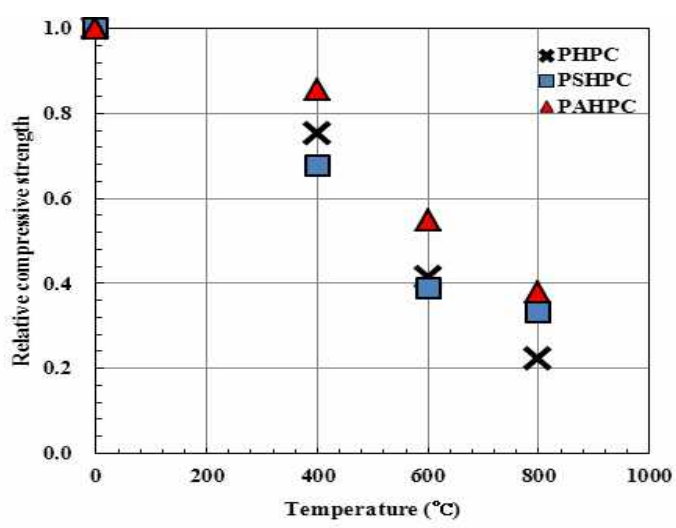

Figure 9. Relative compressive strength with regard to temperature

Figure 10 shows the relative residual strength for the non-spalled mixtures. The relative residual strength was defined as the ratio of the compressive strength of specimen after heating to that at room temperature. As seen in the figure, the ratio of PAHPC was highest among the fiber mixture. PAHPC shows 15\% higher value in residual compressive strength rate than PSHPC at $400^{\circ} \mathrm{C}$ and $600^{\circ} \mathrm{C}$. When exposed to $800^{\circ} \mathrm{C}$, the rate of PAHPC shows less significant performance ( $9 \%$ higher than PSHPC) compared to the lower temperature exposure.

\subsubsection{Elastic modulus}

Figure 11 shows the relative elastic modulus of the test specimens after exposure to high temperature. The relative elastic modulus was defined as the ratio of the elastic modulus of specimen after heating to that at room temperature. The elastic modulus was calculated using the closest measurement value within the range of $1 / 3$ of the peak stress.

The relative elastic modulus of each fiber mixture was decreased to $56 \%$ at $400^{\circ} \mathrm{C}, 21 \%$ at $600^{\circ} \mathrm{C}$, and $8 \%$ at $800^{\circ} \mathrm{C}$. The elastic modulus abruptly decreased within the temperature range of $400-600^{\circ} \mathrm{C}$, and slowly decreased within the temperature range of $600-800^{\circ} \mathrm{C}$.

There were no significant differences in the elastic modulus according to the fiber type at given temperatures. PAHPC showed slightly higher values in the elastic modulus compared to the others two mixtures (PHPC or PSHPC): 5 7\% higher values than others at $400^{\circ} \mathrm{C}, 3 \sim 4 \%$ higher values at $600^{\circ} \mathrm{C}$, and almost the same at $800^{\circ} \mathrm{C}$.
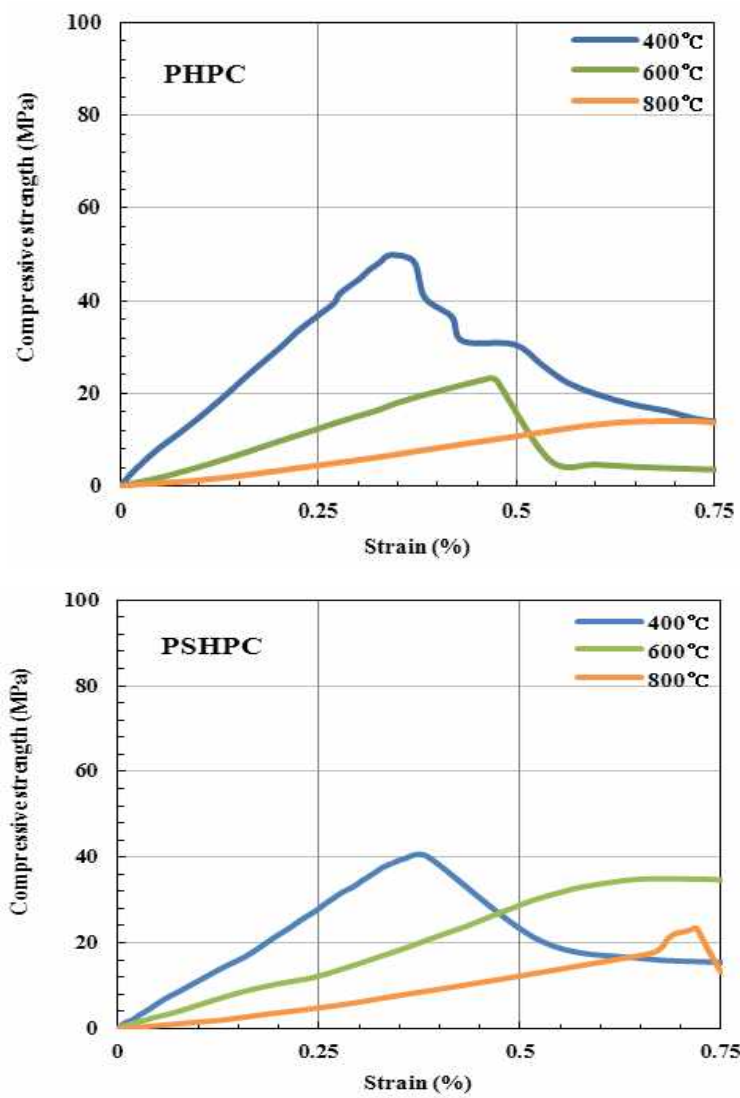


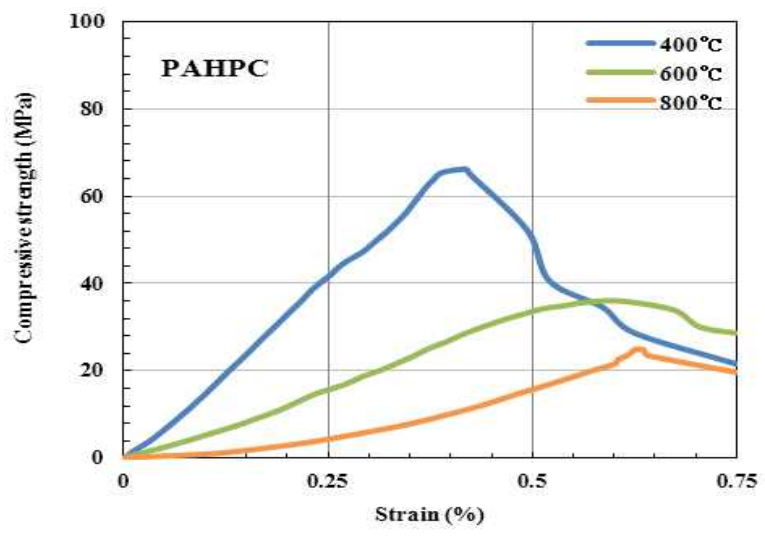

Figure 10. Stress-strain curves for heated concrete

\subsubsection{Strain at peak stress}

Figure 12 shows the relative peak strain according to temperature. The relative peak strain was defined as the ratio of the strain at peak stress of specimen after heating to that at room temperature.

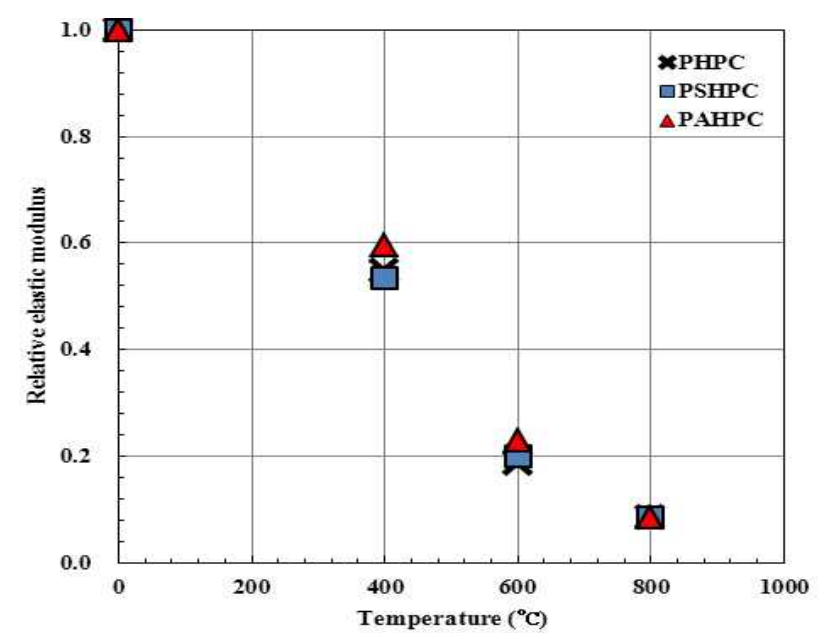

Figure 11. Relative elastic modulus

The relative peak strain increased with the increase of temperature, and no significant differences among the fiber types. They were 1.2 times higher at $400^{\circ} \mathrm{C}, 1.9$ times higher at $600^{\circ} \mathrm{C}$, and 2.4 times higher at $800^{\circ} \mathrm{C}$ than those of the unheated concrete.

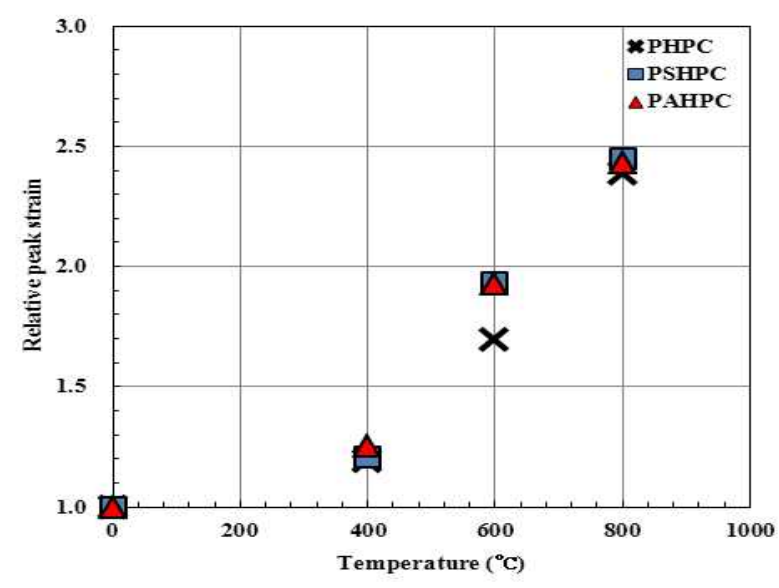

Figure 12. Relative peak strain

\subsubsection{Residual energy absorption capability}

Figure 13 shows the relative residual energy absorption capability of the test specimens after exposure to high temperature. The relative residual energy absorption was defined as the area under the stress-strain curve up to the strain value of $0.75 \%$ after heating to that at room temperature. After exposure to high temperature, the overall average relative energy absorption capability was $77 \%$ at $400^{\circ} \mathrm{C}, 47 \%$ at $600^{\circ} \mathrm{C}$, and $26 \%$ at $800{ }^{\circ} \mathrm{C}$. This trend was similar to that of the residual compressive strength rate.

The residual energy absorption capability by mixed fiber was highest at $82 \% \mathrm{PHPC}$ at $400^{\circ} \mathrm{C}$; and at $53 \%$ when $\mathrm{PAHPC}$ at $600^{\circ} \mathrm{C}$. At the temperature of $800^{\circ} \mathrm{C}$, the residual energy absorption capability was highest PAHPC.

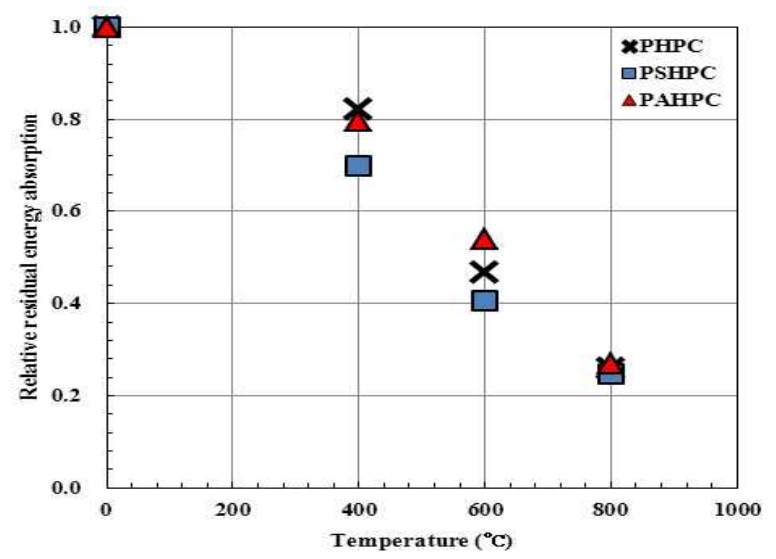

Figure 13. Relative residual energy absorption 


\section{Discussion}

\subsection{Explosive spalling resistance}

As explosive explosive spalling is governed by a vapor-pressure mechanism, it is reasonable to consider that the use of PP fibers can prevent the concrete from explosive explosive spalling, due to the fact that polypropylene fibers are melted under temperature around $165^{\circ} \mathrm{C}$ and moisture in concrete can escape through inter-connected pores to outside of concrete. However, from the result of SHPC and AHPC, the use of metal fiber alone cannot prevent the explosive spalling due to the fact that the melting points of steel fibers and amorphous metal fibers are much higher than the temperature occurred spalling.

\subsection{Material properties after high temperature exposure}

The mechanical properties are degenerated with the increase of temperature. By comparing the test result of two similar fiber ingredient mixtures, PSHPC and PAHPC, we can observe several interesting facts. PAHPC showed a better anti-firing resistance than PSHPC through the temperature range examined in this investigation. However, the outperformance of PAHPC compared to PSHPC at higher temperature $\left(800^{\circ} \mathrm{C}\right)$ is not as significant as those at lower temperature. We could observe this tendency in the residual strength, in strain at peak stress, and also in residual energy absorption. This relatively lower performance of PAHPC at higher temperature seems to be due to the structural change of AMF. The amorphous structure changes into crystalline one due to high temperature hence it loose the benefit of amorphous structure [5].

\section{Conclusion}

The investigation revealed the outperformance of the AMF high strength concrete in high temperature. The fireproof characteristic was most pronounced in the concrete mixed with $\mathrm{AMF}+\mathrm{PPF}$ in terms of the residual compressive strength, residual elastic modulus, peak strain, and residual energy absorption capability.

The investigation also re-confirmed the usefulness of polymer type fiber under high temperature condition, i.e. PPFs were melted and made paths for the vapor pressure discharge hence the concrete using PPF (PPF alone, $\mathrm{PPF}+\mathrm{SF}, \mathrm{PPF}$ $+\mathrm{AMF})$ were free from the explosive spalling. However, the plain concrete and the concrete with metal fiber ingredient (SF mixture and $\mathrm{AMF}$ mixture) showed explosive spalling since they could not form a network for a vapor pressure discharge.

\section{Acknowledgements}

This research was supported by both a grant from Cutting-edge Urban Development Program funded by Ministry of Land, Transport and Maritime Affairs of Korean government (Grant No.11CHUD-B059195-000000) and a research grant funded by POSCO.

\section{References}

1. Kalifa P, Menneteau PD, Quenard D. Spalling of concrete pore pressure in HPC at high temperatures. Cement and Concrete Research. 2000 December;30(1):1915-27.

2. Chana YN, Luob X, Sunb W. Compressive strength and pore structure on residual high performance concrete after exposure to high temperature up to $800^{\circ} \mathrm{C}$. Cement and Concrete Research. 2000 February;30(2):247-51.

3. Penga GF, Yangb WW, Zhaoa J, Liua YF, Biana SH, Zhaoa $\mathrm{LH}$. Explosive spalling and residual mechanical properties of fiber toughened high performance concrete subjected to high temperatures. Cement and Concrete Research. 2006 April;36(4):723-7. 
4. Poon CS, Shui ZH, Lam L. Compressive behavior of fiber reinforced high performance concrete subjected to elevated temperature. Cement and Concrete Research. 2004 December;34(12):2215-22.

5. Luborsky FE. Amorphous metallic alloys. 1st ed. Michigan:Butterworth-Heinemann;1983. 534 p.

6. Oucief H, Zeghiche J, Fanutza C, Habita MF. Hybrid fiber reinforced self compacting concrete:Fiber synergy at low fiber volume fraction. Journal of Civil Engineering Research and Practice. 2006;3(1):21-9.

7. ASTM International. ASTM C143 Standard Test Method for Slump of Hydraulic Cement Concrete. American Society for Testing and Materials; 2010.

8. ASTM International. ASTM C231 Standard Test Method for Air Content of Freshly Mixed Concrete by the Pressure Method. American Society for Testing and Materials; 2010.

9. ASTM International. ASTM C39 Standard Test Method for Compressive Strength of Cylindrical Concrete Specimens. American Society for Testing and Materials; 2010.

10. JSCE. JSCE-SF5 Method of Test for Compressive Strength and Compressive Toughness of Steel Fibre-Reinforced Concrete. Concrete library of JSCE; 1984.

11. Poon CS, Azhar S, Anson M, Wong YL. Comparison of the strength and durability of normal and high strength pozzolanic concretes at elevated temperatures. Cement and Concrete Research. 2001 September;31(9):1291-300.

12. Poon CS, Azhar S, Anson M, Wong YL. Performance of metakaolin concrete at high temperatures. Cement and Concrete Composite. 2003 January;25(1):83-9.

13. Wu B, Su XP, Li H, Yuan J. Effect of high temperature on residual mechanical properties of confined and unconfined high strength concrete. ACI Materials Journal. 2002 July; 99(4):399-407.

14. Chan SYN, Peng GF, Anson M. Fire behavior of high performance concrete made with silica fume at various moisture contents. ACI Materials Journal. 1999 May;96(3): 405-9.

15. Taerwe LR. Influence of steel fiber on strain- softening of high strength concrete. ACI Materials Journal. 1993 January;89(1):54-60.

16. Nataraja MC, Dhang N, Gupta AP. Stress-strain curves for steel fiber reinforced concrete under compression. Cement and Concrete Composite. 1999 December;21(5-6):383-90. 